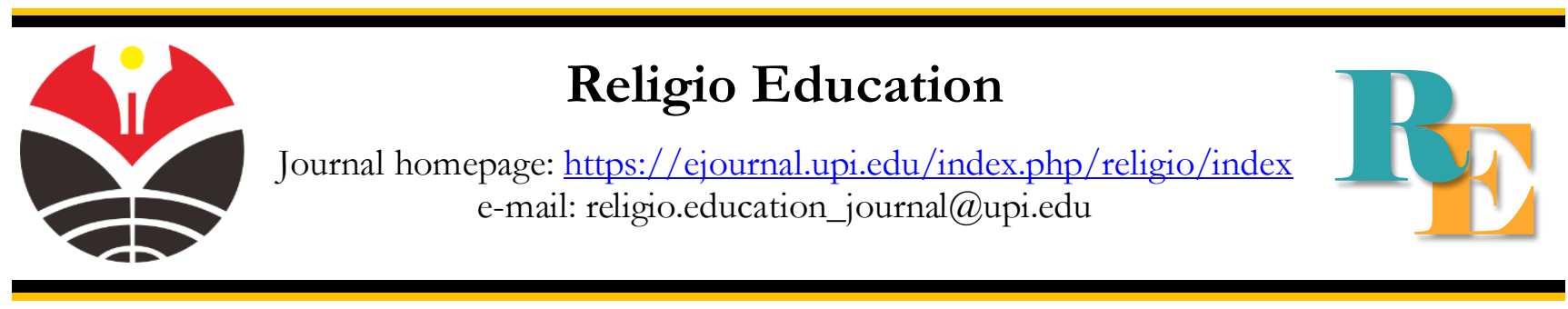

\title{
INTERNALIZATION OF ISLAMIC VALUES IN THE 21st CENTURY CONSTRUCTION ORNAMENTS
}

\author{
Olivia de H. Basoeki \\ Graduate School of Technological and Vocational Education, National Yunlin University of Science \\ and Technology, Yunlin, Taiwan \\ d10843012@gemail.yuntech.edu.tw \\ Wu Mingchang \\ Graduate School of Technological and Vocational Education, National Yunlin University of Science \\ and Technology, Yunlin, Taiwan \\ wumc@yuntech.edu.tw
}

*Correspondence: d10843012@gemail.yuntech.edu.tw

\begin{abstract}
A bst ract s
This article aims to determine the concepts as well as some Islamic construction ornaments that contain Islamic values. Art and spirituality will not be complete if they do not touch on architecture, so Islamic architecture has an important meaning from the perspective of spirituality. In the $21^{\text {st }}$ century, there are architectural issues in how buildings respond to the environment. Therefore, buildings including ornaments must be environmentally friendly and apply the concept of simplicity design and apply appropriate technology. The research used is library research with descriptive methods. The result of this research is that the art of decoration is one of the most important character building elements in Islamic architecture. Types of typical Middle Eastern ornaments include calligraphy, geometric ornaments, and arabesk.
\end{abstract}

\begin{tabular}{l}
\hline A r t i c l e I n f o \\
\hline Article History: \\
Received 10 Agustus 2021 \\
Revised 17 September 2021 \\
Accepted 12 Oktober 2021 \\
Available online 15 November 2021 \\
\\
Keyword: \\
Islamic Values; \\
Ornaments; \\
$21^{\text {st }}$ Century Construction.
\end{tabular}

\section{Introduction}

Islamic art is an artist's creation that contains and expresses beauty, artistic and aesthetic values which, on the one hand, expresses spirit and culture and reflects the world view and Islamic view of life in space and time (Santoso \& Salim, 2018). Art and spirituality will not be complete if they do not include architectural elements, then architecture has an important meaning from the perspective of spirituality (Hujaeri, 2019). In Islam, architecture is part of the practice of Islamic law. The symbols contained in Islamic architecture contain deep meanings and culminate in the greatness and greatness of Allah Swt.

Every building that characterizes Islamic values emits a physical dimension (outer) that is visible to the five senses, as well as a metaphysical dimension (batiniyah) that can be captured by reason and taste (Parhan et al., 2021). From these two dimensions, forming a unity of reality that cannot be separated (Wasilah, et. Al. 2018). Therefore, every Islamic building cannot eliminate these two dimensions. The basic philosophy of architecture and art which can be 
extracted from the Islamic worldview is a reminder of the unity and greatness of Allah SWT. This basic philosophy is related to the purpose of human existence in the world, namely to worship Allah (Putrie \& Hosiah, 2012a). Worshiping is not only carrying out prayers five times a day, designing buildings based on Islamic values can also be of worship value. Thus, Muslims who see or are in the building can remember Allah. Islamic architecture according to Wasilah, et. al (2018) must reflect buildings that meet the following characteristics: 1). Expression of awareness about the majesty and greatness of Allah Swt; 2). Manifestation of the function of the human caliphate on earth; 3). Media of self-servitude to the Creator and maintenance of relationships with fellow humans; 4). Utilization of resources for human welfare and happiness, both physically and mentally; and 5). Maintenance of harmony and preservation of nature as a gift from Allah Swt.

While Ghozali \& Zuhri (2020) explained that the art of Islamic architecture has a series of architectural elements that are often present and make it unique, including: 1). Geometric motives, namely simple forms of geometric patterns combined or unified to form designs; 2). Vegetal Pattern, namely elements that have plant representation patterns and have no symbolic meaning; 3). Calligraphy, namely Qur'anic verses are often written in this form to strengthen the message and also be aesthetically attractive; 4). Minarets or towers, namely the basic elements of Islamic architecture in the form of towers with onion shaper crowns; 5). Domes, which is the most common element of the mosque and is the main symbol of the mosque; 6). Fountains / Water, namely decorative elements that can serve as a cooling source; 7). Light, namely by adding to the quality of a more dynamic architectural appearance through the use of lighting to increase the texture and contrast of elements; and 8). Other Elements, which are elements that appear in building elements, such as gardens, arches, columns or pages.

Entering the 21st century, there are architectural issues on how buildings are able to respond to their environment. Therefore, various theories such as critical regionalism as well as the concept of green and sustainability in a tropical perspective present a more critical design approach for each region. In this regard, functionality is the same as being prioritized by simplicity design products. The terminology of simplicity or simple in modern architectural dictionaries is intended to describe a part of the method, facade expression and structure, architectural form or form in general, as well as its emphasis on functional aspects, including minimizing development costs or means of production (Syahid, 2015).

The 21st century architectural art, including the ornaments used, must be environmentally friendly and apply the concept of simplicity design, which means that the building or ornament that is made must be multifunctional and the costs incurred are not too high. This means that the building or ornament that is designed must apply appropriate technology. Appropriate technology is technology designed for a particular society so that it can be adapted to the environmental, ethical, cultural, social, political and economic aspects of the community concerned. From the desired goal, appropriate technology must apply a method that is resource efficient, easy to maintain, and has a minimal polluting impact compared to mainstream technology, which generally emits a lot of waste and pollutes the environment (Imran, 2018). The Islamic values contained in architectural art and construction ornaments made in the 21st century are interesting to be investigated further, so that these Islamic values can become concepts, references and guidelines to be used as constructions and ornaments with Islamic values, not only aesthetic values, but also ethical, symbolic, philosophical and religious values (Parhan et al., 2020) and effectiveness is a consideration in an architecture with Islamic values.

\section{Methods}


The research used is library research or library research, namely through data collection or analysis carried out to solve problems from relevant library materials. The method used is descriptive method that aims to find and describe the forms of ornamentation in Islamic buildings. Primary data is used through data collection studies literature on several ornaments related to the theory of the form and elements of Islamic architecture. Secondary data used are books that are relevant to the problems that are the research discussion. After the data is collected, the authors analyze the results of these data with content analysis techniques so that the authors discuss in depth the contents of some of the information found. The steps in this analytical research begin with determining the design or research model, then searching for primary data and secondary data. Furthermore, the search for contextual knowledge is interrelated between discussions.

\section{Results and Discussion \\ Construction Ornaments}

Ornament comes from the word "Ornare" (Latin) means to decorate. Ornament also means decoration, so ornament is often referred to as decorative design or decorative design. Ornament is a geometric style decoration or a form of handicraft, including architecture and interior (Supatmo, 2016). In architecture, ornamentation is a decoration used in buildings, an attempt to cover or disguise the original form of a material or structure used in the building. Ornaments are decorative patterns that are drawn, sculpted and printed, with the aim of supporting improving the quality and value of an object or work of art (Putrie \& Hosiah, 2012a). Apart from having aesthetic value, in Islam, ornamentation has a function as a reminder of God's innocence (taubid) (Budiyanti et al., 2020), the transfiguration of materials and structures, and beauty is an essential manifestation of Muslim aesthetic values in order to create awareness of divine transcendence, which is the core of spirituality and astirsic creation with the environment (Supatmo \& Syafii, 2016). This indicates that the ornament is a decoration or decoration made by drawing, sculpting, or printing. Ornaments are made with the aim of disguising the original form of the building material or structure. Islamic ornaments can generally be found in mosques, but also in madrasas or residences (Sidiq, 2011).

Facing the 21 st century, the ornaments used use environmentally friendly materials and apply appropriate technology so that what is emphasized in their manufacture is in terms of their function or usefulness. This is in accordance with the basic philosophy of Islamic architecture and art so that the ornament becomes a means of remembering tawbid, the oneness and greatness of Allah Almighty (Budiyanti et al., 2020). Then the ornament is made to further optimize this function but without losing its aesthetic value (Sundari \& Yulimarni, 2020). The patterns and motifs used in ornamentation in Islamic art and architecture are mostly geometric, calligraphic, and nature-inspired patterns such as stalactites, honeycombs, flowers, leaves, and plant tendrils (Putrie \& Hosiah, 2012a). These patterns can be made with techniques and materials that cost little, are environmentally friendly, and of course contain Islamic values (Juliana, J., \& Zaharani, 2019).

In the teachings of Islam, there is a prohibition on making naturalistic ornaments of humans, animals, or animate living things (Budiwiyanto, 2005); (Hadiwinoto, 2014) In one of the hadiths, the Prophet Muhammad said "Indeed, a house in which there is a picture / painting (animate) will not be entered by the angels". Therefore, to keep decorating the building without leaving the elements of art, flower, geometric, and calligraphy ornaments from the three sometimes stand alone, or collaborate between the three (Pramono, 2012). The arrangement of ornaments is usually carried out repeatedly (repetition) and continuously alternates so that it can depict certain pattern elements in two-dimensional or three-dimensional forms and each has a specific purpose and function (Wasilah, et. Al, 2018). 


\section{Types of Construction Ornaments}

The art of decoration is one of the most important character building elements in Islamic architecture. Types of ornaments typical of the middle east, including as disclosed (Nirmala, et. al. 2019) as follows:

\section{Calligraphy}

Etymologically, calligraphy comes from English, calligraphy comes from two Greek syllables, namely kallos: beauty (beautiful) and graphein: to write (to write) which means beautiful writing or the art of beautiful writing (Anwar, 2018). In Arabic calligraphy is called fann al-khath (art of writing) (Huda, 2017). The word calligraphy can be interpreted as a line or writing. People who are experts in the field of calligraphy are called khath-thaath (calligraphers) (Somad, 2006).

Calligraphy making has the main goal, namely to benefit from the sentences of the Qur'an so that it can increase the Greatness of Allah and remind that Muhammad is His Messenger (Kusyanto \& Nandang, 2020). Calligraphy has an essence that comes from the values and concepts of faith in the verses of the Qur'an (Kirom \& Hakim, 2020). Thus, calligraphy affects other forms of artistic expression or cultural expression in general. Judged from an aesthetic point of view (Somad, 2006), according Al-Faruqi, (1995) Calligraphy is the pinnacle of Islamic art which has multiple artistic values, namely: 1). Is a form of Arabesk. The notion that calligraphy as Arabesk can be seen from the flexibility of calligraphic forms that can be created into multivariates, such as wavy, stretched, bent, tilted, designed to be rigid, angular or cursive, and can be given floral ornate patterns or geometric patterns; 2). Its appearance has a discursive value. The artistic value of calligraphy comes from how it presents implied meanings directly to the mind. This is evident from the way calligraphy conveys holy messages from the verses of the Qur'an or the Hadiths of the Prophet, even when the calligraphy is displayed apart from the verses of the Koran or the Hadiths of the Prophet, such as aphorisms, proverbs, names -the name of God (Asmäul Husnä).

\section{Geometric Ornaments}

Geometric motifis a type of shape that is used as a starting point / initial idea in making ornaments that have a function to show attention, recognize, and give the impression of feeling (Purwanto, 2010). Geometric motifs are very popular in the world of Islamic art and are widely used to decorate various media such as walls, floors, ceilings, flower vases, lamps, books and textiles (Nirmala, et. al. 2019).

The implementation of geometry in making basic shape ornaments is a circle combined with a square (root proportion system 2) and a circle nominated by a triangle (root proportion system 3 ). The root proportion system 2 uses the ratio of the sides of the square to the diagonal of the square, namely $1: \sqrt{ } 2$. Meanwhile, the root proportion system 3 uses a ratio of the ratio of the half base to the height that divides the two equilateral triangles as Pramono (2012) show in the following image.
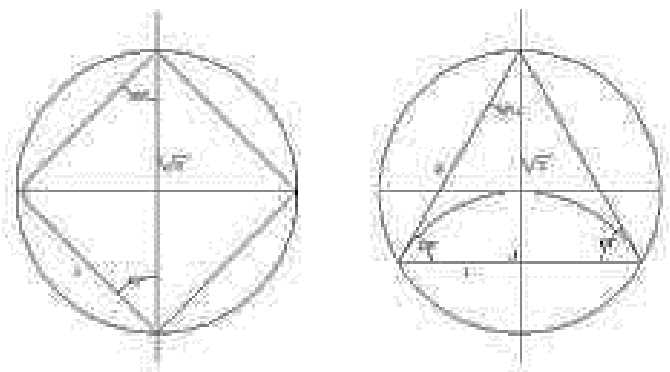

Figure.1 Proportion system $\sqrt{2}$ and $\sqrt{3}$

From the two systems of proportions, it is followed by the method of rotation and intersection of the lines. Next, we get imaginary lines resulting from the rotation of the object 
and the intersection of the lines that touch it. On these imaginary lines, a line is drawn to form a pattern which can be repeated vertically and horizontally (Pramono, 2012). The concept of geometry in Islamic architecture is basically an appearance obtained by repeating units by emphasizing a symmetrical shape accompanied by scale changes in the repetition process so that certain mathematical patterns are created such as in decorative elements on floor patterns, walls and other mosque elements (Kusyanto \& Nandang, 2020).

\section{Arabesk (Arabesque)}

Arabesk motifs are pictures or carvings with tendrils, leaves, branches, or trees (Azhar, 2013). Muslim artists developed Arabesk art from Byzantine era culture (Yunus et. al., 2012). In practice, Arabesk shapes can be combined with calligraphy and geometric ornaments, as shown by Pramono (2012); (Nirmala, et. Al., 2019) as follows:

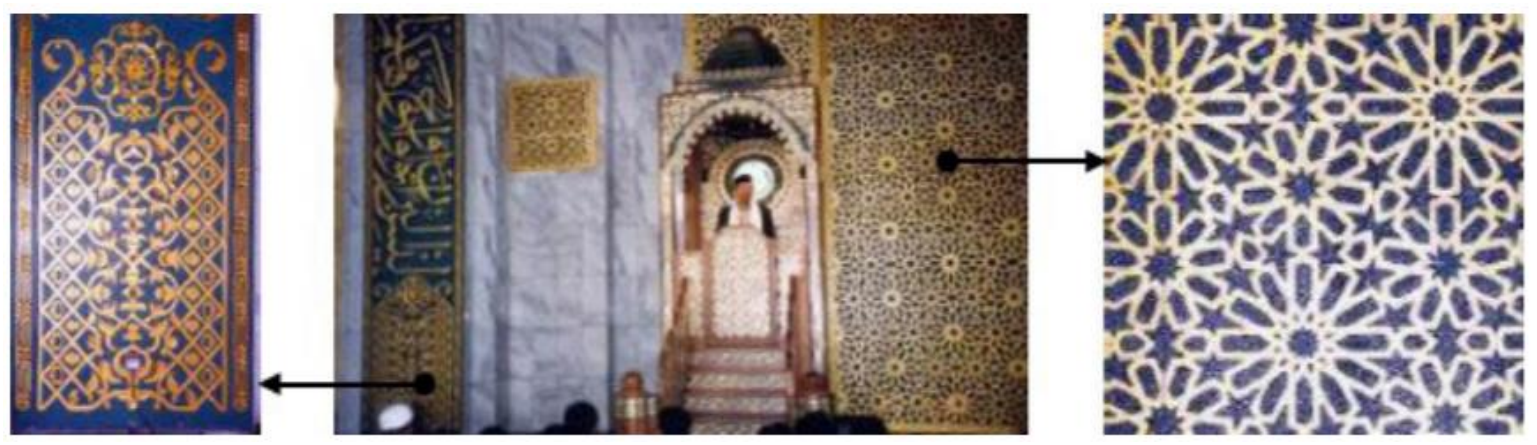

Picture. 2. Examples of arabesk motifs

Apart from the three typical Middle Eastern ornaments, there are also spatial decorative ornaments, namely muqarnas, which are a form of three-dimensional decoration in the interior of the building's dome, which is inspired by the geometric composition of honeycombs (Putrie, 2010). The word muqarnas comes from Arabic, which means stalactite dome (Musyarofah, nd). Muqarnas designs are applied to domes, gate niches, windows, columns and room ceilings as below:
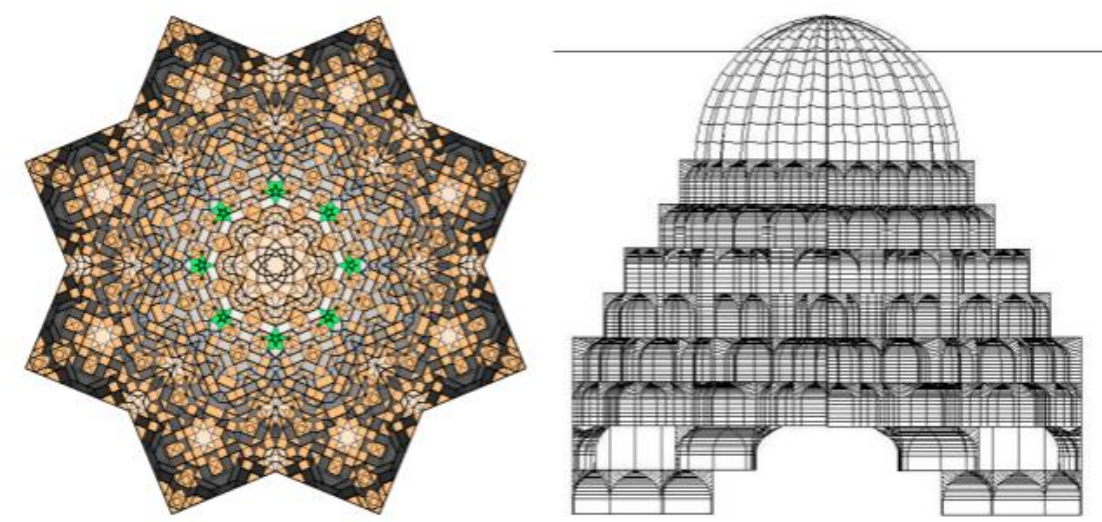

Picture. 3. Projection of two muqarnas dimensions

The three-dimensional texture that muqarnas have, make muqarnas reflect and diffuse the light that comes in from outside, into the space below. As a result, the space receives diffuse light that is evenly distributed and less glare. Light that enters through the windows around the dome and hits the geometric recesses of muqarnas, produces a dramatic visual effect and touches the three-dimensional consciousness (space) of the observer (Putrie \& Hosiah, 2012a). 
Apart from muqarnas, another ornament is water. In its development, water is not only used as a means of purifying (ablution) but becomes an essential component in Islamic decoration as well as an illustration of the presence of natural elements (Hablumminal alam) in buildings. Water is used as a decorative element such as in a pond where it can create a reflection of buildings and all other decorations (Kusyanto \& Nandang, 2020).

\section{Construction Ornament Function}

The presence of ornament does not merely fill in a blank part of an object or work, but obeys Supatmo (2016) has certain functions, including: 1). The purely aesthetic function is the function of ornament to beautify the appearance of objects that are decorated so that they become works of art; 2). Symbolic function, ornamentation is generally applied to products of ceremonial objects or heirlooms of a religious or belief nature; 3). The technical function of construction, ornament plays a structural role to support, support, connect or strengthen construction.

According to Adolf Loos in Nirmala, et. al (2019) ornaments in architecture have two functions, including: 1). As a pure decoration: made only to decorate for the beauty of a form (object) or building where the ornament is placed. Its application is usually in household appliances, architecture, on clothing (batik, embroidery, filigree) on means of transportation and so on; 2). As a symbolic decoration: apart from having a function to decorate an object, it also has certain symbolic values in it, according to certain norms (customs, religion, other social systems). The form, motive and placement are very much determined by these norms, especially religious norms that must be obeyed, to avoid misunderstanding of the symbolic meaning or value contained therein.

The beauty of ornamentation considers Islamic values, namely benefit, avoidance of harm, monotheism, and cleanliness. The disadvantages that must be avoided in ornamentation are the tendency to exaggerate (mubadzir)(Budiyanti et al., 2016), the depiction of animate beings, the causes of disturbed concentration, the intention to boast, being extravagant, the causes of difficulties in maintaining cleanliness in the future, and so on (Putrie \& Hosiah, 2012b). Thus, the mudharat includes the dangers that befall the physical and the religion, such as causing shirk, arrogance, and redemption, while the mudharat in architecture can be caused by errors or lack of consideration when designing a work.

According to al-Faruqi in Santoso \& Salim (2018) states that ornamental designs have implied value and function in them which are classified into four parts, namely: 1). Reminiscent of Tawheed. The beautiful, intricate and infinite patterns found in the art of Islamic ornamentation are a real aesthetic effort of Muslims to create art products that make the viewer feel God's transcendence. 2) Material Transfiguration. Islamic art is an art that emphasizes abstraction or denaturalization in the choice and use of subject matter. How artists use materials is also influenced by the desire to obtain ways of expression in accordance with Islamic teachings. The term transfiguration implies that change is not merely change but change that elevates, glorifies and increases the value of spirituality. 3). Structural Transfiguration. Ornamentation in every work of Islamic art plays a role of structural transfiguration by covering the basic forms or reducing the impression of these basic forms to the audience. 4). Transfer. This function is universal in aesthetic creations, namely the use of ornaments to beautify and decorate. The ornamentation found in Islamic art works provides an additional dimension to connoisseurs of Muslim art, because every image or object, expression or movement, line or story that expresses Tawhid, for Muslims is an expression of truth and virtue.

\section{Conclusion}


In religion Islam, architecture is part of the practice of Islamic law. The symbols contained in Islamic architecture contain deep meanings and culminate in the greatness and greatness of Allah Swt. In the 21st century, buildings, including the ornaments used, must be environmentally friendly and apply the concept of simplicity design, meaning that the building or ornament that is made must be multifunctional and the costs incurred are not too high. Then the design must apply appropriate technology. Types of ornaments typical of the Middle East, including calligraphy, geometric ornaments, and arabesk. Besides that, there are also threedimensional ornaments, namely muqarnas and water. The beauty of ornamentation must consider Islamic values, namely benefit, avoidance of harm, monotheism, and cleanliness.

\section{References}

Al-Faruqi, I. R. (1995). Tawhid: Its Implications for Thought and Life. Herndon.

Anwar, S. (2018). Kaligrafi Desakralisasi Seniman Muslim. Tawshiyah: Jurnal Sosial Keagamaan Dan Pendidikan Islam, 13(2), 72-85. DOI: https://doi.org/10.32923/taw.v13i2.1345

Azhar, N. (2013). Desain interior solo islamic center ( dengan gaya arsitektur islam). Universitas Sebelas Maret.

Budiwiyanto, J. (2005). Tinjauan tentang perkembangan pengaruh local genius dalam seni bangunan sakral (keagamaan) di Indonesia. Ornamen: Jurnal Kria Isi Surakarta, 5(5).

Budiyanti, N., Aziz, A. A., \& Indonesia, U. P. (2020). the Formulation of the Goal of Insan Kamil As a Basis for the Development of Islamic Education Curriculum. IJECA: Iternational Journal of Education and Curriculum Application, 3(2), 1-10. DOI: https://doi.org/10.31764/ijeca.v3i2.2252

Budiyanti, N., Rizal, A. S., \& Sumarna, E. (2016). IMPLIKASI KONSEP ŪLŪL TLMI DALAM AL-QUR 'ĀN TERHADAP TEORI PENDIDIKAN ISLAM (Studi Analisis Terhadap Sepuluh Tafsīr Mu'tabarah). TARBAWY : Indonesian Journal of Islamic Education. https://doi.org/10.17509/t.v3i1.3459

Ghozali, I., \& Zuhri, S. (2020). Elemen Dekorasi Arsitektur Masjid sebagai Komponen Daya Tarik pada Wisata Religi. Tsaqofah Dan Tarikb: Jurnal Kebudayaan Dan Sejarab Islam, 5(1), 91 96. DOI: http://dx.doi.org/10.29300/ttjksi.v5i1.3114

Hadiwinoto, A. (2014). Sinkretisme Dalam Arsitektur. Nalars: Jurnal Arsitektur, 13(1), 23-30. DOI: https://doi.org/10.24853/nalars.13.1.\%25p

Huda, N. (2017). Implementasi Jenis Khat Naskhi dalam Pembelajaran Bahasa Arab. AlMahära: Jurnal Pendidikan Bahasa Arab, 3(2), 287-312.

Hujaeri, A. (2019). Estetika islam: arsitektur masjïd perspektif Seyyed Hossein Nasr. UIN Syarif Hidayatullah.

Imran, M. (2018). Material Konstruksi Ramah Lingkungan Dengan Penerapan Teknologi Tepat Guna. Radial: Jurnal Peradaban Sains, Rekayasa Dan Teknologi, 6(2), 145-157. DOI: https://doi.org/10.37971/radial.v6i2.173

Juliana, J., \& Zaharani, H. (2019). Revitalisasi Filosofi Ornamen Bermotif Melayu pada Desain Corak Anyaman Gedebong Pisang: Kajian Kearifan Lokal Budaya Melayu. Jumal Ilmiah Lingua Idea, 10(1), 12-28. DOI: https://doi.org/10.20884/1.jli.2019.10.1.1541 
Kirom, S., \& Hakim, A. L. (2020). Kaligrafi Islam Dalam Perspektif Filsafat Seni. Refleksi: Jurnal Filsafat Dan Pemikiran Islam, 20(1), 55-67. DOI: 10.14421/ref.2020.2001-04

Kusyanto, M., \& Nandang, D. (2020). Implementasi Ekspresi Islam Sebagai Arsitektur Berbasis Kearifan Lokal ( Studi Kasus : Masjid Sunan Kalijaga Demak ). TALENTA Conference Series: Energy \& Engineering, 3(1), 83-91. DOI: http://dx.doi.org/10.30984/j.v3i2.863

MUSYAROFAH, A. A. (n.d.). Etnomatematika pada Ornamen Masjid Roudhotul Muchlisin Jember Sebagai Lembar Kerja Siswa. Universitas Jember.

Nirmala, A. P. H., Violaningtyas, O. A., \& Damayanti, R. A. (2019). Ornamen Islam Pada Bangunan Arsitektur Masjid Dian Al Mahri Kubah Emas Depok. Jurnal Dimensi Seni Rupa Dan Desain, 16(1), 29-42. DOI: 10.25105/dim.v16i1.6159

Parhan, M., Ghoni, D. A., Nisa, H. N., \& Kimkim, M. (2021). Ngalayad Dan Kebatan: Korelasi Tradisi Budaya Sunda Dengan Kewajiban Seorang Muslim Dalam Bertetangga. Purwadita: Jurnal Agama Dan Budaya, 5(1), 81-92.

Parhan, M., Islamy, M. R. F., Budiyanti, N., Nugraha, R. H., \& Hyangsewu, P. (2020). Responding to Islamophobia by Internalizing the Value of Islam Rahmatan lil Alamin through Using the Media. Islam Realitas: Journal of Islamic and Social Studies, 6(2), 137-149. https://doi.org/http://dx.doi.org/10.30983/islam_realitas.v6i2.3695

Pramono, A. (2012). Pola Geometri Pada Seni Dan Arsitektur Islam Di Andalusia. Journal of Islamic Architecture, 1(3), 133-136. DOI: https://doi.org/10.18860/jia.v1i3.1772

Purwanto, Y. (2010). Seni Dalam Pandangan Alquran. Jurnal Sosioteknologi, 9(19), 782-796.

Putrie, Y. E. (2010). MUQARNAS: Ungkapan Keagungan Nilai Islam dalam Karya Arsitektur. El Harakah, 12(3), 229-238. DOI: https://doi.org/10.18860/el.v0i0.453

Putrie, Y. E., \& Hosiah, A. (2012a). Keindahan Dan Ornamentasi Dalam Perspektif Arsitektur Islam. Journal of Islamic Architecture, 2(1), 48-51. DOI: https://doi.org/10.18860/jia.v2i1.2106

Santoso, M. B., \& Salim, M. S. (2018). Prinsip Transendental dalam Seni Visual Islam. Tasfiyah, 2(2), 271-306.

Sidiq, A. (2011). Masjid Besar Kauman Semarang : Sebuah Kajian Gaya Arsitektur dan Ornamen, Analisa: Journal of Social Science and Religion, 18(1), 39-58. DOI: https://doi.org/10.18784/analisa.v18i1.123

Somad, A. (2006). Sejarah Perkembangan Seni Kaligrafi Islam di Indonesia (studi kasus kaligrafi dekorasi di dinding masjid agung al-að̧ar kebayoran barat jakarta). Fakultas Adab Dan Humaniora UIN Syahid.

Sundari, S., \& Yulimarni. (2020). Estetik Ornamen Masjid di Kota Padang. Jurnal Seni, Desain Dan Budaya, 5(1), 1-9. DOI: http://dx.doi.org/10.36982/jsdb.v5i1.1454

Supatmo. (2016). Keragaman Seni Hias Bangunan Bersejarah Masjid Agung Demak. Jurnal Imajinasi, X(2), 107-120. DOI: https://doi.org/10.15294/imajinasi.v10i2.8805

Supatmo, \& Syafii. (2016). Keragaman Seni Hias Bangunan Bersejarah Masjid Agung Demak. Imajinasi: Jurnal Seni, 10(2), 107-120. DOI: https://doi.org/10.15294/imajinasi.v10i2.8805

Syahid, M. A. A. (2015). Sustainabilitas arsitektur masjid: Evaluasi konsep "Simple Architecture" sebagai implementasi desain arsitektur berkelanjutan suatu kawasan. Seminar Nasional Sains Dan Teknologi, 1-8. 
105 | Religio Education, November 2021, Volume 1, Issue 2, 97-105.

Wasilah, W., Ferial, A. S., Alfiah, A., \& Said, N. (2018). Teknik Gambar dalam Perspektif Integrasi Islam. Tanahindie Press.

Yunus, P. P., Soedarsono, \& Gustami, S. (2012). Unsur Estetika Islam Pada Seni Hias Istana Raja Bugis. Jurnal Al- Ulum, 12(1), 35-52. 